
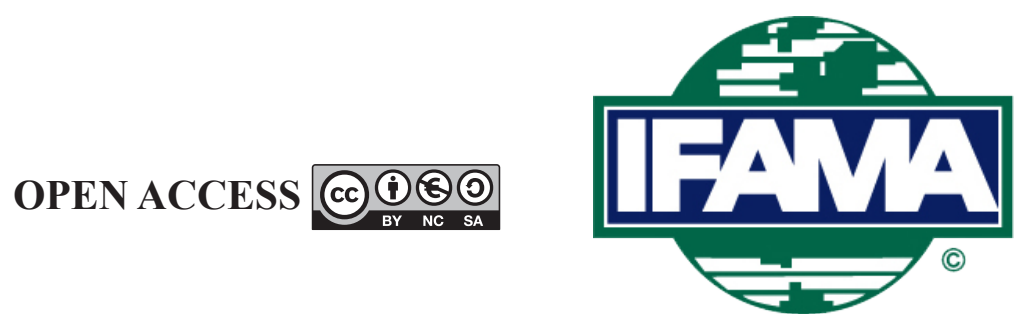

International Food and Agribusiness Management Review

Volume 23, Issue 3, 2020; DOI: 10.22434/IFAMR2019.0160

30 September 2019 / Accepted: 13 April 2020

\title{
Generic promotion of Norwegian seafood exports
}

\author{
RESEARCH ARTICLE \\ Gary W. Williams ${ }^{\oplus a}$ and Oral Capps, Jr ${ }^{b}$ \\ ${ }^{a}$ Professor and Co-Director, ${ }^{b}$ Regents Professor and Co-Director of the Agribusiness, Food, \\ and Consumer Economics Research Center, Department of Agricultural Economics, Texas \\ A\&M University, 2124 TAMU, 600 Kimbrough Dr., College Station, TX 77845-2124, USA
}

\begin{abstract}
The Norwegian Seafood Council (NSC) works cooperatively with its seafood industry to develop foreign demand for Norwegian seafood through generic promotion and advertising. The generic promotion activities are financed through fees levied on all Norwegian seafood exports. Using an econometric simulation approach, the study addresses two key questions regarding the NSC generic seafood export promotion programs over time: (1) What have been the effects of those programs on the Norwegian seafood export volume, price, and revenue in the aggregate? (2) Have Norwegian seafood producers, exporters, and other stakeholders benefitted from the export-levy-funded generic export promotion programs? Examining potential scenarios for a likely range of the price responsiveness of the Norwegian seafood export supply, the study finds that NSC promotion added about $12 \%$ to the aggregate export value of Norwegian seafood between 2003 and 2017 resulting from an addition to the export price and volume of $10 \%$ and $4 \%$, respectively. About $17 \%$ of stakeholder profits over that period was due to the promotion programs resulting in an industry profit benefit to cost ratio of about 12 to 13 to one.
\end{abstract}

Keywords: Norway, seafood exports, generic advertising and promotion, econometric simulation model, benefit-cost analysis

JEL code: Q17, F14, Q22

\footnotetext{
(i)Corresponding author: gwwilliams@tamu.edu
} 


\section{Introduction}

Seafood is now the most traded major food in the world, more than all other animal proteins combined (Anderson et al., 2018; Tveterås et al., 2012). Over the last two decades, seafood became Norway's second largest export earner (behind petroleum) as a result of strong foreign demand bolstered by a weak Norwegian Kroner (NOK) despite lower harvests, disease challenges in aquaculture production, a Russian ban on Norwegian imports, and concerns about access to Chinese markets. The Norwegian Seafood Council (NSC) headquartered in Tromsø, Norway, works cooperatively with the Norwegian seafood industry to develop foreign markets for Norwegian seafood ${ }^{1}$. The industry finances NSC generic export promotion activities through fees levied on all Norwegian seafood exports. Other countries promote their seafood exports with similar generic programs, including the United States (USDA export market development programs ${ }^{2}$ ), Brazil (Apex-Brasil), Chile (ProChile), India (Marine Products Export Development Authority), the UK (Seafish), and Ireland (Bord Iascaigh Mhara) among many others. In addition, a total of 685 promotional campaigns and projects to promote the consumption of fishery and aquaculture products and to improve the image of those products were carried out between 2007 and 2015 in 26 EU Member States by both public and private entities (EUFOMA, 2017).

Like the numerous other generic promotion programs around the world for generally homogenous commodities (e.g. Colombian coffee, Mexican avocados, U.S. wheat and soybeans, New Zealand lamb, and many more), NSC seafood export promotion is a cooperative effort paid for by suppliers to enhance their individual and collective profitability (Ward, 2006; Williams and Capps, 2006). The primary goal of generic promotion is to enhance the market demand for the promoted commodity in an effort to raise sales volume and price for the benefit of the producers who pay for the promotion. In contrast, brand advertising touts the qualities of the product of a specific firm in an industry of related but differentiated products (e.g. shirts, shoes, and laundry detergents) in an effort to enhance the product's market share and sales (Kinnucan and Clary, 1995; Williams and Capps, 2006). A major strategic concern for the export-promoting organizations like NSC is that those who pay for the generic promotion activities operate at the front end of the supply chain while consumers are far downstream at the opposite end, often in distant countries as noted by Love et al. (2001). As a result, they conduct their generic advertising and promotion campaigns at the retail end of the supply chain in many foreign markets under the assumption that sufficient benefits will migrate upstream to stakeholders to more than cover the cost of the advertising and promotion activities they fund.

The focus of this article is the contribution of NSC generic promotion activities to the aggregate volume, price, and revenue of Norwegian seafood exports and the returns to stakeholders, the seafood producers and exporters who fund the generic seafood export promotion program. After a background discussion of Norwegian seafood exports and NSC generic seafood promotion expenditures, pertinent literature is reviewed. The methodology and data are then outlined followed by a discussion of the results of applying that methodology to measure the relationship between NSC generic export promotion and Norwegian seafood exports from January 2003 through December 2017. Finally, major conclusions flowing from the analysis are highlighted.

\section{Norwegian seafood exports and promotion expenditures}

Pushed by productivity growth and cost reductions in aquaculture production, the annual volume of Norwegian seafood exports increased by over 40\% between 2003 and 2017 from 1.7 million metric tons (mt) to 2.4 million $\mathrm{mt}$, respectively ${ }^{3}$. The share of Norwegian seafood exports accounted for by salmon and trout, the primary Norwegian aquaculture species, increased from 40\% in 2003 to over $70 \%$ in 2017 (NSC, 2018). The fresh/chilled product share is now about two-thirds of the total. Over the same period, the annual average

\footnotetext{
${ }^{1}$ In this study, the term 'seafood' includes both captured and farmed seafood. The term 'seafood industry' includes both fisheries and aquaculture. 2 For more detail on these programs, see Reimer et al. (2017) and USDA (2018).

${ }^{3}$ Bergesen and Tveterås (2019) and Rocha-Aponte and Tveterås (2019) provide excellent analyses of the factors behind the growth in Norwegian aquaculture production.
} 
nominal price of aggregate Norwegian seafood exports increased by nearly $165 \%$ from $15.08 \mathrm{NOK} / \mathrm{kg}$ (US\$ 2.13/kg) in 2003 to $39.83 \mathrm{NOK} / \mathrm{kg}$ (US\$ 4.82/kg) in 2017. Consequently, the nominal value of Norwegian seafood exports has risen by almost $270 \%$ from 25.0 billion NOK (US\$ 3.5 billion) to 91.9 billion NOK (US\$ 11.1 billion) over that period. The monthly volume and value of aggregate Norwegian seafood exports have exhibited strong seasonal patterns with highs generally in the last quarter of the year through the first quarter of the following year and lows during the summer months (Figure 1).

Norway exported $90-95 \%$ of its seafood production ${ }^{4}$ to nearly 190 different countries between January 2003 and December 2017 (NSC, 2018). The top ten countries accounted for slightly more than $80 \%$ of those exports and the top 20 only $90 \%$. The euro area was the largest importing region accounting for an average of $27.1 \%$ of those exports followed by Denmark (13.3\%), the Russian Federation (10.5\%), Poland (5.8\%), China (5.3\%), Japan (5.2\%), the UK (4.9\%), Ukraine (4.8\%), Sweden (2.8\%), and Nigeria (2.2\%).

Established in 1991, the NSC is a public company owned by the Norwegian government (NSC, 2018). The Norwegian Ministry of Trade, Industry and Fisheries appoints the NSC board of directors for 2-year terms. NSC is the approval authority for Norwegian seafood exporters. The NSC also acts as an advisor for the Ministry of Trade, Industry and Fisheries in affairs concerning seafood exports and trade. NSC seafood export promotion activities are financed by a levy of $0.30 \%$ to $0.75 \%$ on the value of Norwegian seafood exports. The levies are delineated by species, including salmon, trout, whitefish (such as cod and haddock), cured whitefish, pelagics (such as mackerel and herring), and shellfish.

Between January 2003 and December 2017, the Norwegian seafood industry invested a total of over 4.75 billion NOK (US\$ 719.4 million) to promote exports of their seafood products (NSC, 2018). Annual expenditures over that period ranged from a low of 149.8 million NOK (US\$22.2 million) to a high of 501.3 million

\footnotetext{
${ }^{4}$ More information on Norwegian landings of fish and the management system can be found, for example, in Guttormsen and Roll (2011) and Cojocaru et al. (2019).
}

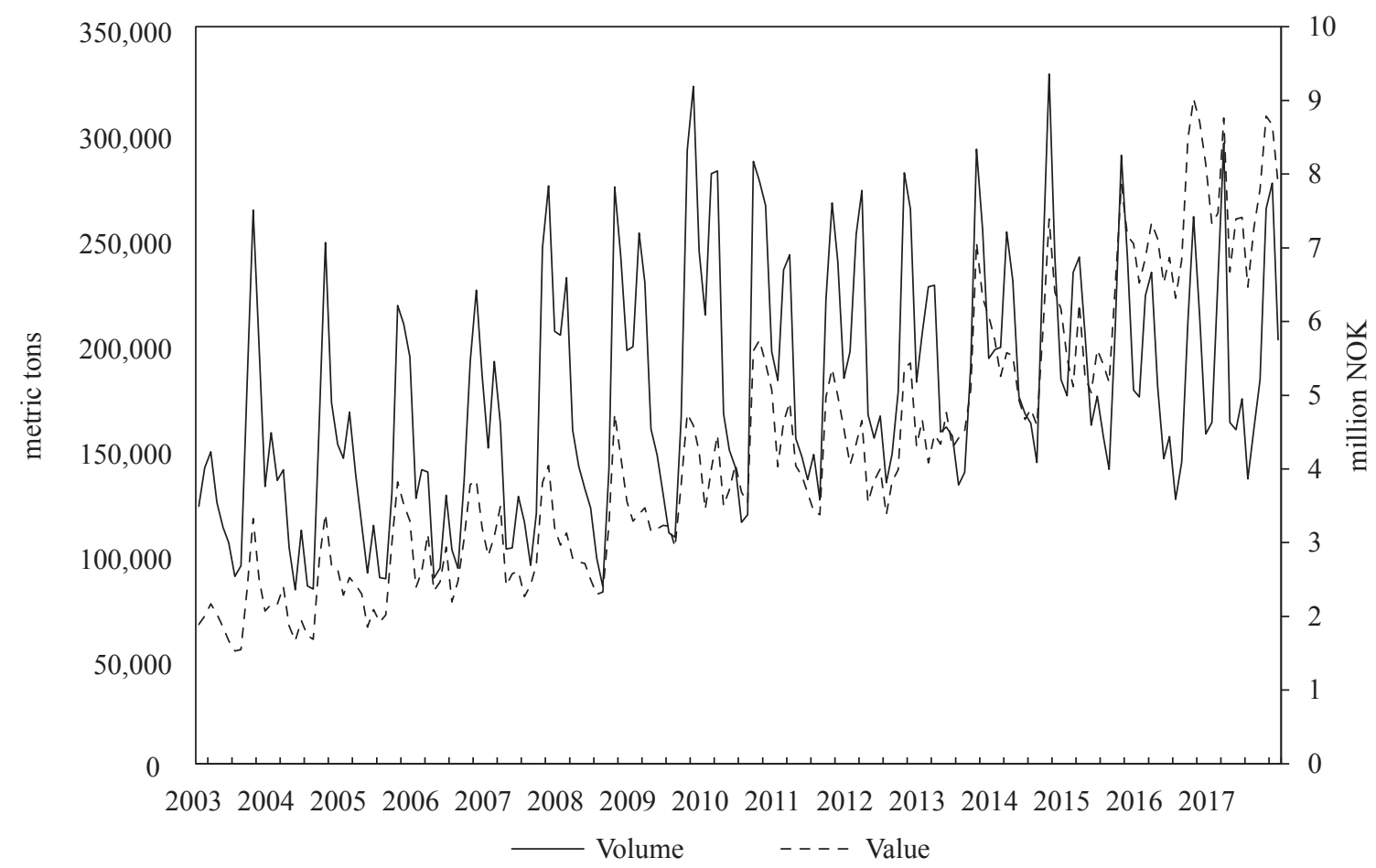

Figure 1. Monthly Norwegian seafood exports, 2003-2017 (NSC, 2018). 
NOK (US\$ 73.0 million). Monthly expenditures on seafood export promotion have been as variable over time as export revenue but with an independent seasonal pattern that has increased markedly in recent years with highs generally in October, November, and December and lows in January, February, and April. The promotion intensity (the ratio of total promotion expenditures to the value of Norwegian seafood exports) averaged only $0.62 \%$ over the period. A low promotion intensity is common for export promotion programs (Kinnucan and Cai, 2011).

Despite the strong upward trend in the nominal NOK value of NSC promotion, price inflation in major foreign markets for Norwegian seafood and a general depreciation in the value of the NOK against the currencies in those countries, particularly since 2012, eroded the real purchasing power of those expenditures in the markets where NSC conducts promotional activities ${ }^{5}$. While annual nominal expenditures have nearly tripled since the low point of 2004, the real purchasing power of those expenditures has only doubled.

\section{Previous studies}

U.S. producer-financed agricultural commodity promotion (checkoff) programs have been the focus of much of the previous research on export demand promotion effectiveness. The vast majority of the large and growing body of that literature concludes that export promotion programs have been statistically significant drivers of their respective export demands and that the benefits to stakeholders have exceeded the costs (Reimer et al., 2017; Williams et al., 2016).

One of the most studied non-U.S. export demand promotion programs is that of the NSC. Although the effects of NSC export promotion across all species promoted have not been previously analyzed, numerous studies have considered various aspects of NSC salmon export promotion programs, most of which have been authored by Kinnucan, Myrland, Xie, and Kaiser (Table 1). A study by CAPIA (2016) analyzed NSC promotion of two Norwegian whitefish, skrei and fresh cod.

Myrland and Kinnucan (2000) conducted an econometric analysis of data from Pan-European surveys and concluded that NSC salmon export promotion increased at-home salmon consumption in the French and German markets by 9.0 and 8.7\%, respectively, in 1998/99. Based on that work, Kinnucan and Myrland (2001) calculated a range of estimates for NSC salmon promotion elasticities for France and Germany of 0.039 to 0.059 and 0.032 to 0.054 , respectively. They used those elasticities to calculate a range of (marginal) benefit-cost ratios (BCRs) for Norwegian salmon promotion in France and Germany of 0.59 to 1.37 and -0.08 to 0.26 , respectively (Table 1). In most of their subsequent work on salmon export promotion, Kinnucan and Myrland assume promotion elasticities in the range of those first published in their 2001 study (about 0.04). In their 2002 study, they estimated a BCR for salmon promotion of between 2.56 to 3.03, substantially different from the estimates for France and Germany in their 2001 study.

Xie (2008) conducted an econometric analysis of the NSC salmon export promotion program using monthly data for January 1998 through July 2007. She reported a salmon export promotion elasticity of 0.046 and a marginal BCR in the range of 5.93 to 6.19. A subsequent econometric analysis by Xie et al. (2009) reported a substantially lower NSC salmon promotion elasticity and BCR of 0.013 and 2.34, respectively. Xie updated her econometric results in 2015 and reported a salmon export promotion elasticity and BCR of 0.054 and 7.95, respectively, more in line with her original 2008 analysis.

Kaiser (2015) considered nine countries in his analysis of the Norwegian salmon export promotion program (Finland, France, Italy, Germany, Poland, Portugal, Spain, Sweden, and the Czech Republic) over the period of 2004-2014. Using an econometric modeling approach and quarterly panel data, he concluded that the key drivers of Norwegian salmon export demand were the export price of salmon, the gross domestic product (GDP) in the importing countries, and NSC export promotion expenditures. He reported an own-

\footnotetext{
${ }^{5}$ The calculation of the real purchasing power of NSC expenditures is discussed later.
} 
Table 1. Previously reported promotion elasticities and benefit-cost ratios for Norwegian Seafood Council seafood export promotion.

\begin{tabular}{|c|c|c|c|c|c|}
\hline \multirow[t]{2}{*}{ Seafood product } & \multirow[t]{2}{*}{ Study } & \multirow{2}{*}{$\begin{array}{l}\text { Estimation time } \\
\text { period }\end{array}$} & \multirow{2}{*}{$\begin{array}{l}\text { Promotion } \\
\text { elasticity }\end{array}$} & \multicolumn{2}{|l|}{ Benefit-cost ratio } \\
\hline & & & & Marginal & Average \\
\hline Salmon & $\begin{array}{l}\text { Myrland and } \\
\text { Kinnucan (2000) }\end{array}$ & 1998/99 & $\begin{array}{l}0.039-0.059 \\
\text { (France) } \\
0.032-0.054 \\
\text { (Germany) }\end{array}$ & $\begin{array}{l}0.59-1.37 \\
\text { (France) } \\
-0.08-0.26 \\
\text { (Germany) }\end{array}$ & - \\
\hline Salmon & $\begin{array}{l}\text { Kinnucan and } \\
\text { Myrland (2000) }\end{array}$ & Assumed & $0.01-0.10$ & - & - \\
\hline Salmon & $\begin{array}{l}\text { Kinnucan and } \\
\text { Myrland (2001) }\end{array}$ & Assumed & $\begin{array}{l}\text { uses Myrland and } \\
\text { Kinnucan (2000) } \\
\text { results }\end{array}$ & - & - \\
\hline Salmon & $\begin{array}{l}\text { Kinnucan and } \\
\text { Myrland (2002) }\end{array}$ & Assumed & 0.04 & - & $2.56-3.03$ \\
\hline Salmon & $\begin{array}{l}\text { Kinnucan and } \\
\text { Myrland (2003) }\end{array}$ & Assumed & 0.04 & - & - \\
\hline Salmon & $\begin{array}{l}\text { Kinnucan and } \\
\text { Myrland (2006) }\end{array}$ & Assumed & 0.038 & - & - \\
\hline Salmon & Xie (2008) & $1998-2007$ & 0.054 & $5.93-6.19$ & - \\
\hline Salmon & Xie et al. (2009) & $1998-2007$ & 0.0133 & 2.34 & - \\
\hline Salmon & Xie (2015) & $1998-2007$ & 0.054 & - & 7.95 \\
\hline Salmon & Kaiser (2015) & 2004-2014 & 0.036 & - & $4.95-9.53$ \\
\hline Skrei & CAPIA AS (2016) & $2003-2015$ & - & $\begin{array}{l}10.3(2003-2013) \\
13.7(2014-2015)\end{array}$ & 1.02 \\
\hline Fresh cod & CAPIA AS (2016) & $2003-2015$ & - & 14.5 & 4.56 \\
\hline
\end{tabular}

price elasticity of Norwegian salmon demand by those countries of -0.491 , a GDP elasticity of 0.108 , and an export promotion expenditure elasticity of 0.036, similar to that used by Kinnucan, Myrland, and Xie in many of their studies. He concluded that NSC salmon export promotion contributed $15.1 \%$ to the average annual volume of Norwegian salmon exports over the study period and reported an export promotion BCR of between 4.95 and 9.3 depending on the export supply elasticity assumed. Following the methodology of Kaiser (2015) and using quarterly data for 2003-2015, CAPIA (2016) calculated an average BCR for NSC skrie and fresh cod promotion of 1.02 and 4.56, respectively.

\section{Methodology and data}

This analysis focuses on the effectiveness of NSC promotion across all Norwegian seafood exports, not just salmon, and to all countries that import from Norway, not just the EU, as most studies have done. For the analysis, we posit a simple three-equation conceptual model for Norwegian seafood export trade:

$$
\begin{aligned}
& \left.\operatorname{NSXD}_{t}=\operatorname{NSXD}_{(N S P X}, G_{t}, Z_{t}\right) \\
& N S X S t=N S X S\left(N S P X /(1+\theta)_{t}, Z_{t}\right) \\
& \operatorname{NSXS}_{t}=\operatorname{NSXD}_{t}
\end{aligned}
$$

where NSXD is the Norwegian seafood export demand aggregated over all destinations; NSXS is the export supply of aggregate Norwegian seafood; NSPX is the weighted average price of aggregate Norwegian seafood exports paid by importers; $\theta$ is the ad valorem weighted average promotion levy assessed by NSC 
on seafood exports; NSPX $_{t} /(1+\theta)_{t}$ is the price received by Norwegian seafood exporters for their exports (=NSP); G is a 'goodwill' variable representing NSC export promotion expenditures ${ }^{6}$; ZD is a matrix of all other demand shift variables, including income (GDP) measures for importing countries, exchange rates relative to the NOK for those countries, competing fish export prices, inflation, and numerous qualitative events that have impacted Norwegian seafood exports over the period of 2003 through 2017; and ZS is an equivalent matrix of appropriate supply shift variables.

After discussing the econometric estimation of Equation 1, the export supply response to price in Equation 2 is then considered. The counter-factual simulation process used to measure the price and export response to NSC export promotion expenditures is then discussed followed by an explanation of the benefit-cost analysis procedure used.

\subsection{Norwegian seafood export demand analysis}

The specification of the aggregate export demand for Norwegian seafood (Equation 1) benefitted from the work of Kaiser (2015) and Williams et al. (2016) as well as many of the export promotion studies reviewed by Williams et al. (2016). The dependent variable in Equation 1 is the monthly aggregate demand for Norwegian seafood exports (NSXD). The monthly price variable (NSPX) is the export unit value of all Norwegian seafood product exports expressed in NOK per kilogram $(\mathrm{kg})$. To account for changes in currency values, NSPX was exchange-rate-adjusted using a monthly trade-weighted exchange rate index in euros per NOK (base period 2010) across the top ten importing countries. The trade-weighted NOK exchange rate index was developed using monthly exchange rate data from IMF (2018) for the top 10 countries that imported seafood from Norway from 2003 through 2017. The trade weights were the shares of Norwegian seafood exports accounted for by those importing countries (NSC, 2018). The FAO aquaculture fish price index (Tveterås, personal communication; Tveterås et al., 2012) was also included in the equation to account for the price pressure on Norwegian seafood exports from growing competing global export supplies of aquaculture fish species like tilapia and pangasius ${ }^{7}$.

The 'goodwill' variable G in Equation 1 is a transformation of NSC seafood export promotion expenditures to account for several key characteristics of the relationship between those expenditures and seafood exports, including: (1) seasonality; (2) purchasing power in foreign countries due to inflation and exchange rate changes; (3) the lag between the time periods of expenditure and the demand impact; and (4) the diminishing marginal impact of promotion expenditures on demand. Seasonal patterns (albeit different) are evident in both NSC expenditures and the aggregate volume of Norwegian seafood exports. To avoid confounding associated with seasonality, we seasonally adjusted the NSC expenditures using the X13 technique (EVIEWS 9.5, IHS Global Inc., London, UK). NSC expenditures were also exchange-rate-adjusted as done for the aggregate seafood price (NSPX) and inflation-adjusted using a trade-weighted Consumer Price Index (CPI) (base 2010). The trade-weighted aggregate CPI was developed following the same technique used for the trade-weighted exchange rate index. A trade-weighted nominal GDP was developed in the same way and then deflated with the trade weighted CPI to create the real GDP measure used in the analysis.

A large body of literature supports the hypothesis that generic advertising and promotion expenditures have carryover or lagged effects (for example, Capps and Williams, 2011; Forker and Ward, 1993; Ghosh and Williams, 2016; Lee and Brown, 1986; Nerlove and Waugh, 1961; Ward and Dixon, 1989; Williams and Capps, 2018; Williams et al., 2008, 2010). Economic theory provides relatively little guidance as to the structure and length of this dynamic process, however. We follow a common practice in the literature of using the Almon polynomial distributed lag (PDL) formulation to account for the time lag in the impact of the NSC export promotion expenditures on aggregate Norwegian seafood exports.

\footnotetext{
${ }^{6}$ The term 'goodwill' used by Nerlove and Arrow (1962) is a stock variable associated with advertising.

7 Although we account for the effect of aquaculture fish prices on Norwegian seafood exports with the FAO price index, a deficiency of data on competing seafood exports and prices (aquaculture and fisheries) over major competing seafood exporting countries precluded us from endogenizing cross-price effects.
} 
The search for the pattern, polynomial degree, and period over which the promotion expenditures influence Norwegian seafood export demand involved a series of nested ordinary least squares (OLS) regressions. Conventionally, researchers, using statistical criteria like the Akaike Information Criterion (AIC), the Schwarz Loss Criterion (SLC), or the Hannan-Quinn Criterion (HQC), allow the data to suggest the optimal number of lags to include in the specification. Previous research suggests that full impacts of promotion expenditures in a given month occur within no more than a year following the expenditure. Hence, we considered lags of NSC expenditures up to twelve months. The econometric results indicate the short-run (immediate or contemporaneous) effects and long-run or cumulative effects as well as the average length of time (in months) before changes in NSC export promotion expenditures begin affecting the demand for Norwegian seafood exports.

NSC expenditures in Equation 1 were also transformed to capture the effects of diminishing marginal returns associated with advertising wearout (for example, Kinnucan et al., 1993; Stewart and Kamins, 2002). To capture those effects, we implemented a logarithmic transformation of the exchange rate-adjusted, deflated, and seasonally adjusted NSC export promotion expenditures as is commonly done (for example, Williams et al. (2016) and many of the U.S. checkoff promotion studies they review) ${ }^{8}$.

While economic variables like purchasing power in importing countries, the export price, exchange rates, and promotion expenditures explain the long-term trends in exports, various events in global seafood markets may have impacts in specific years or across many years. Attention to these influential events is warranted in any economic analysis (Belsley et al., 1980). For example, the seasonal patterns evident in the volume of monthly Norwegian seafood exports must be accounted for in the analysis. In addition, various qualitative events may affect global seafood markets in particular years and must be taken into account to isolate more accurately the effects of promotion on exports. The major global events with potential to impact Norwegian seafood exports were identified in discussion with NSC personnel and treated as indicator variables in Equation 1. Finally, we consider habit persistence or inertia using a one-period lag in the volume of seafood exports.

\subsection{Norwegian seafood export supply price response}

Equation 2 defines the response of Norwegian seafood export supplies to changes in price. The importance of supply response to a price increase generated by promotion was first discussed in a now classic article by Nerlove and Waugh (1961). Subsequent research has concluded that the supply response to promotion can substantially limit or even completely offset the long-term price effects of promotion programs (for example, Carman and Green, 1993; Kinnucan et al., 1995; Williams et al., 2002).

The critical link between supply response and the effectiveness of export promotion is illustrated in Figure 2. Assume, for example, that the promotion of the foreign demand for Norwegian seafood shifts out the demand for seafood exports in a given year from NSXD ${ }^{\text {wo }}$ to NSXD ${ }^{\mathrm{w}}$ as depicted in Figure 2 (where 'wo' and 'w' mean 'without' and 'with' promotion, respectively). Consistent with Chang and Kinnucan (1991), the ad valorem levies on Norwegian seafood exports behave like excise taxes, the cost of which is shared by producers and consumers. Graphically, the effect is manifest with two export supply curves separated vertically by the weighted average ad valorem promotion levy $(\theta)$. The higher of the two curves (NSXS $(\theta))$ in each case shown in Figure 2 represents the levy-augmented prices offered to foreign consumers (NSPX) at various levels for Norwegian seafood exports. For clarity of exposition and because our focus is the effects of promotion on Norway, the prices received by exporters (NSP) along the levy-reduced export supply curve (NSXS) in each case are highlighted in Figure 2.

\footnotetext{
${ }^{8}$ The proprietary nature of promotion expenditure data over the study period by major competing seafood exporting countries precluded us from estimating the cross effects of Norwegian promotion expenditures and those of competing countries.
} 
If the Norwegian seafood export supply curve is highly elastic like NSXS in Figure 2, most of the adjustment to a successful promotion program is manifest as an increase in export volume $\left(\mathrm{NSX}_{0}^{\mathrm{WO}}\right.$ to $\mathrm{NSX}_{\mathrm{e}}^{\mathrm{W}}$ ) rather than an increase in export price ( $\mathrm{NSP}_{0}^{\mathrm{Wo}}$ to $\mathrm{NSP}_{\mathrm{e}}^{\mathrm{W}}$ ).

Note that the price received by Norwegian exporters for their seafood exports (NSP) is the 'export' price here. Such a vigorous response of export supply to the export price would imply little or no effective regulation limiting the expansion of Norwegian seafood production. In this case, even though the export price increase from the promotion-induced export demand shift is moderated by the export supply response, export sales revenue is higher because the export quantity sold at the somewhat higher export price increases. The total cost of exporting also increases with the higher exports, however, so that the net benefit to the industry in terms of an increase in export surplus ${ }^{9}$ (the horizontally-lined area in Figure 2) is smaller than the net export revenue increase from the tax. The industry net benefit is positive unless the export supply is perfectly price elastic.

A less price-elastic export supply such as $\mathrm{NSXS}_{0}$ in Figure 2 would represent, perhaps, the effects of government efforts to limit Norwegian seafood supply to some extent. In this case, the same shift in the foreign demand for Norwegian seafood from promotion would result in a higher increase in the export price

\footnotetext{
${ }^{9}$ The 'export surplus' is the difference between the gain in producer surplus and the loss in consumer surplus in Norway from a rise in price resulting from the increase in foreign demand for Norwegian seafood. Thus, a change in 'export surplus' is the net gain to the Norwegian economy from the generic promotion of Norwegian seafood exports. Because the domestic market accounts for only about 5-10\% of Norwegian annual seafood production, the export surplus in this case approximates Norwegian seafood producer surplus. Thus, in this article, we use 'export surplus' as the measure of producer surplus. For this reason, an increase in 'export surplus' is deemed the net benefit to the Norwegian seafood industry.
}

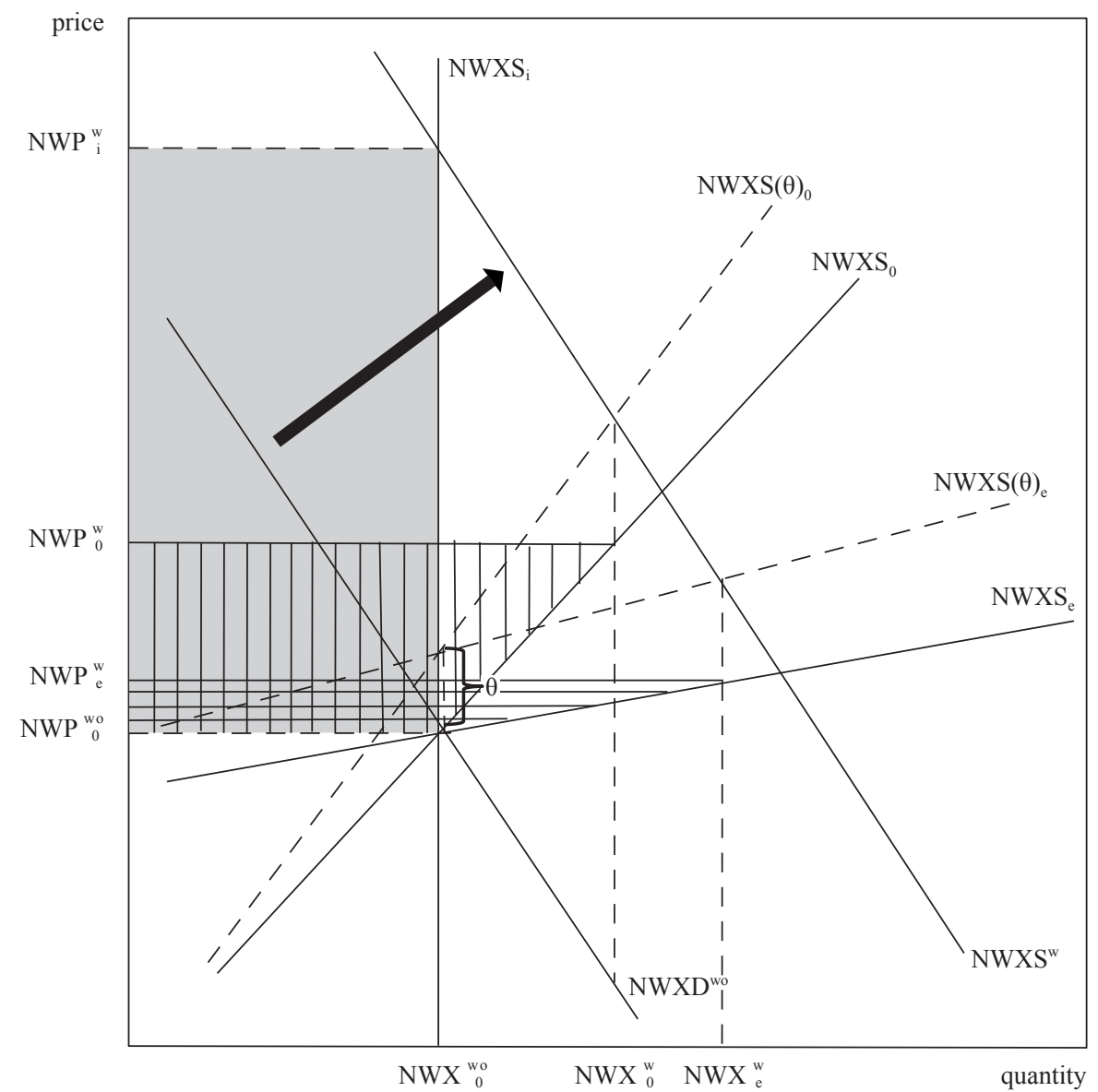

Figure 2. Market and welfare effects of export demand promotion. 
$\left(\mathrm{NSP}_{0}^{\mathrm{wo}}\right.$ to $\left.\mathrm{NSP}_{0}^{\mathrm{w}}\right)$ and a smaller increase in export sales $\left(\mathrm{NSX}_{0}^{\mathrm{wo}}\right.$ to $\left.\mathrm{NSX}_{0}^{\mathrm{w}}\right)$. The resulting increase in the net benefit to the Norwegian seafood industry (the vertically lined area in Figure 2) is larger as a result.

Given a perfectly inelastic export supply $\left(\mathrm{NSXS}_{\mathrm{i}}\right)$ representing an absolute limit on Norwegian seafood export supplies due to effective government controls on seafood production, the adjustment to a successful promotion program is manifest solely as an increase in the export price $\left(\mathrm{NSP}_{0}^{\mathrm{WO}}\right.$ to $\mathrm{NSP}_{\mathrm{i}}^{\mathrm{W}}$ ) leading to additional industry export revenue represented by the shaded rectangle in Figure 2. Thus, even if the export price increases considerably from the promotion, foreign sales cannot increase beyond $\mathrm{NSX}_{0}^{\mathrm{wo}}$ due to the supply restriction. Because export demand promotion has no effect on export volume, export suppliers' costs of exporting do not change. Consequently, the increase in export revenue from the promotion is the addition to export surplus and the net benefit to the industry.

Little is known in general about the price responsiveness of the Norwegian supply of particular seafoods, however, and even less about the price responsiveness of the export supply of aggregate Norwegian seafood. Regulations on Norwegian salmon production tend to focus on managing growth based on biological sustainability rather than limiting expansion, as has been the case with most fisheries (Besson et al., 2017; Hersoug, 2015). Consequently, the supply of aquaculture species is generally considered to be more supply responsive than that of captures species. The literature on the Norwegian salmon supply elasticity, however, is somewhat mixed. Asheim et al. (2011) estimated low domestic short-run and long-run price responsiveness of the Norwegian salmon supply (0.091 in the short run and 0.141 in the long-run). In contrast, Steen et al. (1997), Asche et al. (2007), and Andersen et al. (2008) all estimated a long-run domestic salmon supply elasticity of about 1.4 to 1.5. Many of the NSC salmon promotion studies listed in Table 1 adopted some version of the domestic salmon supply elasticity of 1.54 estimated by Steen et al. (1997) in their analyses. Xie $(2008$, 2015) calculated the elasticity of the Norwegian excess salmon supply to be 1.65. Kaiser (2015) assumed alternative salmon export supply elasticities of 1.0 and 2.0 in his analysis of the NSC salmon promotion program ${ }^{10}$.

In contrast, a sparse literature concludes that the supply of capture species like whitefish and pelagics is largely determined by government-imposed production quotas and not so much by price (Arnason et al., 2004; Pascoe and Mardle, 1999). A few studies using data before Norwegian fishery quota systems were fully binding found that the price elasticity of Norwegian capture fish supplies ranged from inelastic (Salvanes and Squires, 1995) to unitary elastic (Asche, 2009). In more recent modeling of world fish supply by the World Bank, capture fish supplies are assumed to be completely price inelastic (Msangi et al., 2013). They assume the supply elasticity of aquaculture species, however, to be somewhere between 0.5 and 1.0. So over both capture and aquaculture, the supply of fish in the World Bank model would be somewhere between zero and 1.0.

Thus, Norwegian seafood export supplies are not likely to be highly price elastic as represented by NSXS in Figure 2 given that both capture (fishery) and farmed (aquaculture) species are subject to government regulations that control supply to some extent. On the other hand, the aggregate supply of Norwegian seafood exports is not likely to be perfectly inelastic like NSXS $_{\mathrm{i}}$ in Figure 2 either given that the more priceresponsive salmon supply dominates Norwegian seafood exports. In addition, the export supply of seafood is not the same thing as the domestic production of seafood. Export supply curves are normally more elastic than their domestic counterparts because they are the difference between the domestic supply and demand curves. Although Norway exports $90-95 \%$ of its seafood supply (NSC, 2018), the export supply can increase to some extent as the export price increases by drawing down the supply available to the small domestic market. Thus, even if domestic production of all species were strictly controlled, the export supply would be price responsive to some small extent at least.

\footnotetext{
${ }_{10}$ As a reviewer noted, the different estimated supply elasticities may be due in part to different periods of estimation and reflect different points in adoption of new pen-reared salmon production technologies.
} 
If we assume that the supply of capture species is effectively controlled by government quotas, then the elasticity of the Norwegian export supply of such species approaches zero. Further, assuming the export supply elasticity of Norwegian salmon is no higher than about 1.5 and given that salmon represents about two-thirds of all Norwegian seafood exports, the export supply elasticity of Norwegian seafood across both capture and aquaculture species would be no higher than about 1.0. Consequently, in the analysis of the NSC generic seafood promotion program, we consider a plausible range for the Norwegian seafood export supply elasticity of $0,0.5$, and 1.0 .

\subsection{Counterfactual simulation procedure}

To determine the effects of NSC promotion on Norwegian seafood exports, two sets of scenarios were simulated with the model (Equations 1-3) over January 2003 through December 2017 using the econometric results from estimating the parameters of Equation 1 of the model: (1) a 'with NSC export promotion' simulation (referred to as the 'with' scenario); and (2) three 'without NSC export promotion' simulations corresponding to the three alternative Norwegian seafood export supply elasticities considered in the analysis (referred to as the 'without' scenarios).

The 'with' scenario represents actual history, that is, the export volume, value, and price of Norwegian seafood that actually occurred over the period of analysis which include the effects of the NSC seafood export promotion expenditures over time. The three 'without' scenario analyses were conducted by setting both the historic values of NSC seafood export promotion expenditures in Equation 1 and the export levy $(\theta)$ in Equation 2 to zero and then simulating the model using the three alternative export supply elasticities $(0,0.5$, and 1$)$ to determine the likely range of effects from NSC promotion on the Norwegian seafood industry over time.

Differences in the simulated levels of Norwegian seafood export volume, value, and price in the 'with' scenario from those in the three 'without' scenarios represent direct measures of the effects of the NSC seafood export promotion program in each case. No other exogenous variable in the model (e.g. levels of inflation, exchange rates, income levels, etc.) other than the NSC promotion expenditures and the export levy were allowed to change in the three 'without' scenarios.

We note that the use of simulation analysis to account for the price effects of promotion in evaluations of the effectiveness of export promotion programs is standard practice in the literature (Reimer et al., 2017). In Kinnucan and Gong (2014), for example, the change in producer surplus associated with export promotion is approximated as a function of postulated parameters: (1) the own-price elasticity of export demand; (2) the export supply elasticity; (3) the export promotion elasticity; (4) the price elasticity of supply for domestic production; (5) the proportionate change in export price; (6) the proportionate change in export supply; and (7) the proportionate change in 'goodwill' (advertising stock). The amount of advertising in the current period is a function of the current level of goodwill, which, in turn, is a function of current and past advertising outlays. All of the salmon studies in Table 1 except Kaiser (2015) followed a similar process. Our simulation analysis follows an effectively equivalent process except that we explicitly account for the demand-side variables in a structural model in which the parameters are econometrically estimated rather than assumed. A similar approach was adopted by Kaiser (2015) for salmon and by many studies of U.S. export promotion reviewed in Williams et al. (2016).

\subsection{Benefit-cost analysis}

A common measure of the 'benefit' used in benefit-cost analyses of export promotion programs is the additional export revenue generated given that the promotion objective is to increase export sales. As illustrated in Figure 2, an effective NSC seafood export promotion program would be expected to shift out the Norwegian seafood export demand curve resulting in a higher Norwegian seafood export price (NSP') on a higher seafood export volume over time $\left(\mathrm{Q} \mathrm{X}^{\mathrm{w}}\right)$. The magnitude of changes in the price and in the export volume 
depends critically on the magnitude of the export supply elasticity. The simulated additions to Norwegian seafood export revenue (net of the levy revenue) induced by the NSC export promotion program over time $(\mathrm{RX})$ is calculated as:

$$
\mathrm{RX}_{\mathrm{jt}}=\mathrm{NSP}_{\mathrm{jt}}^{\mathrm{W}} \mathrm{NSX}_{\mathrm{jt}}^{\mathrm{W}}-\mathrm{NSP}_{\mathrm{t}}^{\mathrm{Wo}} \mathrm{NSX}_{\mathrm{t}}^{\mathrm{Wo}}
$$

where, as in Figure 2, the superscripts $w$ and wo denote 'with' and 'without' promotion, respectively, $\mathrm{j}$ represents the three alternative export supply elasticities considered $\{0,0.5,1.0\}$, and t refers to a particular year. Both the prices (NSP) and quantities (NSX) in Equation 4 include the supply-shifting, excise-tax-like effects of the levy $(\theta)$ paid in part by Norwegian seafood exporters (see Figure 2).

The Gross Revenue BCR (GBCR) given the excise tax effect of the levy $(\theta)$ is then calculated for each of the three export supply elasticities considered as the additional Norwegian seafood export revenue (RX) generated over the period of promotion from Equation 4 per NOK of promotion expenditure (E) over that period:

$$
\mathrm{GBCR}_{\mathrm{j}}=\sum_{\mathrm{t}=1}^{\mathrm{T}} \frac{\mathrm{RX}_{\mathrm{jt}}}{\mathrm{E}_{\mathrm{t}}}
$$

where $T$ represents the last year of the promotion period. Note that $\mathrm{E}$ does not change as the supply elasticity changes in this ex-post analysis because this ex-post analysis considers the effects of a historically fixed and, therefore, exogenous level of promotion expenditures given different assumptions on the level of export supply responsiveness to price. If the analysis intended to determine the optimal expenditure level rather than the effects of a historically exogenous level of expenditures on exports and prices at different supply elasticities, then the tax-shifting that occurs as a result of the levy would result in different expenditure levels as the export supply elasticity changes as demonstrated by Kinnucan and Myrland (2000).

Because NSC promotion represents a cost of generating the additional seafood export revenue to seafood exporters, the promotion expenditures in each year must be netted out of the additional export revenue they earn to arrive at the net export revenue BCR for each of the three export supply elasticities considered:

$$
\mathrm{NBCR}_{\mathrm{j}}=\sum_{\mathrm{t}=1}^{\mathrm{T}} \frac{\mathrm{RX}_{\mathrm{jt}}-\mathrm{E}_{\mathrm{t}}}{\mathrm{E}_{\mathrm{t}}}
$$

Revenue-based BCRs are often the metric of interest by export promotion groups because revenue generation is typically an explicit goal of promotion. Even so, revenue-based export BCR measures may be misleading as promotion metrics because they fail to account for the additional costs required to generate the additional export revenue. Such costs include the additional production costs, inland transport costs, freight and insurance costs, and so on. To account for such costs, we can calculate the more appropriate change in export surplus (RS) as illustrated in Figure 2, to represent the 'benefit' of the program in year for each of the three export supply elasticities considered:

$$
\mathrm{RS}_{\mathrm{jt}}=\left(\mathrm{NSP}_{\mathrm{jt}}^{\mathrm{w}}-\mathrm{NSP}_{\mathrm{t}}^{\mathrm{wo}}\right) \mathrm{NSX}_{\mathrm{t}}^{\mathrm{wo}}+1 / 2\left(\mathrm{NSX}_{\mathrm{jt}}^{\mathrm{w}}-\mathrm{NSX}_{\mathrm{t}}^{\mathrm{wo}}\right)\left(\mathrm{NSP}_{\mathrm{jt}}^{\mathrm{w}}-\mathrm{NSP}_{\mathrm{t}}^{\mathrm{wo}}\right)^{11}
$$

The net export surplus BCR (SBCR) is calculated by replacing RXjt with RSjt in Equation 6. Although not precisely the same thing, the export surplus which approximates Norwegian seafood producer surplus ${ }^{12}$ can be considered a measure of the Norwegian seafood industry export profit. The concept of the export surplus as 'profit' is particularly applicable to the Norwegian seafood industry which faces supply controls because a higher price in this case primarily increases the profit of individual seafood producers.

\footnotetext{
$\overline{{ }^{11} \text { For each elasticity }(j)}$, the first term in this equation is the area of the rectangle defined by the difference between the higher price (with promotion) and the original price (without promotion) times the export level without promotion. The second term is the area of the triangle defined by the same price difference times $1 / 2$ the difference between the export level with promotion and the export level without promotion. The sum of the two areas approximates export surplus, which is defined in footnote 9.

12 Recall that the domestic market accounts for only about 5-10\% of Norwegian seafood production so that the export surplus approximates producer surplus in this case.
} 


\subsection{Data}

Monthly data on Norwegian seafood export volume and value were provided by NSC along with data on their monthly export promotion expenditures for 2003 to 2017 (NSC, 2018). Data for exogenous variables like exchange rates, inflation rates (CPI), and gross domestic products for importing countries were all obtained from the IMF (2018). The FAO aquaculture price index developed by Tveterås et al. (2012) was obtained from Tveterås (personal communication). Information relating to events impacting Norwegian seafood exports over time was provided by NSC personnel and used to develop indicator variables for the econometric export demand analysis (NSC, 2018).

\section{Analysis of Norwegian seafood export demand promotion}

We investigate the market effects and stakeholder benefits from NSC seafood export demand promotion by first econometrically examining the effects of promotion on Norwegian seafood export demand. We use those results in a counterfactual simulation analysis of the effects of NSC promotion on Norwegian seafood export volume, price, and value. The results are subsequently used in a BCR analysis.

\subsection{Econometric analysis of export demand}

Equation 1 of the model was operationalized for estimation as follows using monthly data for January 2003 to December 2017, a total of 180 observations:

$\log \mathrm{NSXD}_{\mathrm{t}}=\mathrm{f}\left(\log \left(\frac{\mathrm{NSPX}_{\mathrm{t}}}{\mathrm{FAOPI}_{\mathrm{t}}} \mathrm{ER}_{\mathrm{t}}\right), \log \left(\frac{\mathrm{FAOPI}_{\mathrm{t}}}{\mathrm{MCPI}_{\mathrm{t}}}\right), \log \left(\frac{\mathrm{MGDP}_{\mathrm{t}}}{\mathrm{MCPI}_{\mathrm{t}}} \mathrm{ER}_{\mathrm{t}}\right), \mathrm{PDL}\left(\mathrm{G}_{\mathrm{t}-\mathrm{n}}\right), \log \left(\mathrm{NSXD}_{\mathrm{t}-1}\right), \mathrm{SEAS}_{\mathrm{t}}, \mathrm{I}_{\mathrm{t}}\right)($

where NSXD = monthly volume of aggregate Norwegian seafood exports; NSPX = nominal aggregate price of Norwegian seafood exports paid by importing countries; FAOPI = FAO aquaculture price index; ER = trade-weighted index of the NOK exchange rates of the top 10 countries that import seafood from Norway; MGDP = trade-weighted nominal gross domestic product of the top 10 countries that import seafood from Norway; MCPI = trade-weighted CPI of the of the top 10 countries that import seafood from Norway; $\operatorname{PDL}\left(\mathrm{G}_{\mathrm{t}-\mathrm{n}}\right)=$ polynomial distributed lag model of the goodwill stock of Norwegian seafood export promotion expenditures $(\mathrm{G})$ over periods $\mathrm{t}, \mathrm{t}-1 \ldots \mathrm{t}-\mathrm{n}$, where $\mathrm{G}_{\mathrm{t}-\mathrm{n}}=\log \left(\frac{\mathrm{EXP}_{\mathrm{t}-\mathrm{n}}}{\mathrm{MCPI}_{t-n}} \mathrm{ER}_{\mathrm{t}-\mathrm{n}}\right)$, EXP is the seasonally adjusted nominal NSC expenditures to promote Norwegian seafood exports, and $\mathrm{n}$ is the lag length determined as discussed previously; SEAS = seasonal monthly indicator variables with December as the base or reference month; and I = a matrix of indicator variables for various events affecting Norwegian seafood exports.

The estimated coefficients, the standard errors, $t$-statistics, $P$-values and other pertinent information associated with the estimation of Equation 8 are shown in Table 2. As discussed in the methodology section, model selection criteria (AIC, SIC, and HQC) were used to determine the most appropriate equation specification. The equation explains $96 \%$ (adjusted $\mathrm{R}^{2}$ ) of the variation in aggregate Norwegian seafood export demand from January 2003 through December 2017. The signs and magnitudes of all estimated coefficients are consistent with prior expectations. As well, the within-sample mean absolute \% error (MAPE) over the sample period is $6.9 \%$. The goodness-of-fit and the MAPE characteristics indicate a high degree of reliability of the econometric analysis.

The model was estimated in double log form so that the estimated coefficients associated with the continuous explanatory variables are elasticities. The parameters of the model initially were estimated using ordinary least squares. Despite the relatively large number of control or explanatory variables, to avoid the inadvertent omission of any other important quantitative or qualitative factors, the residuals associated with the econometric specification were examined to determine if a systematic pattern exists in those residuals by testing the model for the presence of serial correlation. The Breusch-Godfrey LM test was implemented due to the presence of a lagged dependent variable (Breusch, 1978; Godfrey, 1978). This test is not only more general than the Durbin $h$ statistic but also more powerful statistically. The test concluded that serial correlation was present 
Table 2. Econometric estimation results for the Norwegian seafood export demand equation. ${ }^{1}$

Dependent variable: Norwegian seafood exports (mt) $\begin{aligned} & \begin{array}{l}\text { Parameter } \\ \text { estimate }\end{array} \\ & \text { error }\end{aligned} \quad \begin{aligned} & \text { Standard } \\ & t \text {-value }\end{aligned} \quad P$-value

\begin{tabular}{|c|c|c|c|c|}
\hline \multicolumn{5}{|l|}{ Variables (in natural logs except indicator variables) } \\
\hline Intercept & 3.3638 & 0.9518 & 3.53 & 0.0005 \\
\hline $\begin{array}{l}\text { Norwegian seafood export price/FAO aquaculture price } \\
\text { index (exchange-rate-adjusted) }\end{array}$ & -0.9736 & 0.0485 & -20.08 & 0.0000 \\
\hline $\begin{array}{l}\mathrm{GDP}^{2} \text { of importing countries (real, exchange-rate- } \\
\text { adjusted) }\end{array}$ & 0.3795 & 0.0592 & 6.41 & 0.0000 \\
\hline Seasonal indicator for January & -0.1273 & 0.0241 & -5.28 & 0.0000 \\
\hline Seasonal indicator for February & -0.0849 & 0.0290 & -2.93 & 0.0040 \\
\hline Seasonal indicator for March & -0.0181 & 0.0282 & -0.64 & 0.5218 \\
\hline Seasonal indicator for April & -0.1663 & 0.0292 & -5.69 & 0.0000 \\
\hline Seasonal indicator for May & -0.1764 & 0.0324 & -5.44 & 0.0000 \\
\hline Seasonal indicator for June & -0.1663 & 0.0303 & -5.48 & 0.0000 \\
\hline Seasonal indicator for July & -0.2578 & 0.0327 & -7.88 & 0.0000 \\
\hline Seasonal indicator for August & -0.2278 & 0.0309 & -7.36 & 0.0000 \\
\hline Seasonal indicator for September & 0.0108 & 0.0277 & 0.39 & 0.6984 \\
\hline Seasonal indicator for October & 0.2210 & 0.0272 & 8.12 & 0.0000 \\
\hline Seasonal indicator for November & 0.1320 & 0.0249 & 5.30 & 0.0000 \\
\hline YR_1317 & 0.0413 & 0.0327 & 1.26 & 0.2091 \\
\hline EU trout tariff & -0.1121 & 0.0304 & -3.68 & 0.0003 \\
\hline U.S. punitive duty on Norwegian salmon imports & -0.1650 & 0.0500 & -3.30 & 0.0012 \\
\hline $\begin{array}{l}\text { Free trade agreements with South Africa and } \\
\text { South Korea }\end{array}$ & 0.2120 & 0.0488 & 4.34 & 0.0000 \\
\hline Implementation of maximum allowable biomass regime & 0.1449 & 0.0579 & 2.50 & 0.0134 \\
\hline $\operatorname{AR}(1)^{2}$ & 0.2767 & 0.0720 & 3.85 & 0.0002 \\
\hline $\operatorname{AR}(3)^{2}$ & 0.2951 & 0.0737 & 4.01 & 0.0001 \\
\hline $\operatorname{MA}(19)^{2}$ & -0.6125 & 0.0520 & -11.77 & 0.0000 \\
\hline $\operatorname{MA}(21)^{2}$ & -0.3875 & 0.0550 & -7.04 & 0.0000 \\
\hline \multicolumn{5}{|c|}{ Goodwill variable of $\mathrm{NSC}^{2}$ promotion expenditures (real, exchange-rate adjusted) } \\
\hline NSC promotion expenditures in current period & 0.0167 & 0.0052 & 3.22 & 0.0016 \\
\hline NSC promotion expenditures lagged one period & 0.0278 & 0.0087 & 3.22 & 0.0016 \\
\hline NSC promotion expenditures lagged two periods & 0.0334 & 0.0104 & 3.22 & 0.0016 \\
\hline NSC promotion expenditures lagged three periods & 0.0334 & 0.0104 & 3.22 & 0.0016 \\
\hline NSC promotion expenditures lagged four periods & 0.0278 & 0.0087 & 3.22 & 0.0016 \\
\hline NSC promotion expenditures lagged five periods & 0.0167 & 0.0052 & 3.22 & 0.0016 \\
\hline Sum of lags & 0.1558 & 0.0485 & 3.22 & 0.0016 \\
\hline \multicolumn{5}{|l|}{ Regression statistics: Adj. $\mathrm{R}^{2}=0.96436 ; \mathrm{DW}=1.9606$} \\
\hline
\end{tabular}

necessitating the use of generalized least squares. The analysis determined that the pattern in the residuals was attributable to autoregressive processes of the error terms of orders 1 and 3 (AR(1) and AR(3) in Table 2) and moving-average processes of orders 19 and 21 (MA(19) and MA(21) in Table 2). These autoregressive and moving-average patterns likely are associated with weather, production cycles, government policies and other unspecified non-economic forces affecting the volume of Norwegian seafood exports not captured by the explanatory variables. 
Additional tests of potential sensitivity of model results were conducted, including tests for autoregressive conditional heteroscedasticity in the residuals (ARCH effects). These tests indicated the absence of any heteroscedasticity in the residuals over time. The issue of price endogeneity was examined using a WuHausman test by comparing instrument variable (IV) estimates (two-stage least squares (2SLS) estimates) to OLS estimates (Hausman, 1978; $\mathrm{Wu}, 1973$ ). The hypothesis of the exogeneity of price was not rejected ${ }^{13}$. Like most export promotion analyses, promotion expenditures are treated as predetermined in our model (see studies reviewed by Williams et al., 2016). That is, the NSC determines the level of promotion expenditures based on decisions made by their board members. In turn, we explore the impact of those predetermined expenditure levels on the volume of Norwegian seafood exports.

The econometric results for Equation 8 indicate that Norwegian seafood export demand is negatively related to the aggregate real export price of Norwegian seafood and positively related to real GDP with estimated elasticities of -0.974 and 0.38 , respectively (Table 2). Kaiser (2015) reports lower estimates of both elasticities for Norwegian salmon demand across the nine importing countries he considers. Due to collinearity issues between the real Norwegian whitefish price and the real FAO aquaculture price index, we use the ratio of the two as a single regressor. Thus, the FAO aquaculture price index acts as a deflator of the real aggregate export price of Norwegian seafood.

Seasonality also plays a role in the demand for aggregate Norwegian seafood exports as indicated in Table 2. Exports of Norwegian seafood products tend to be lower in January through August of each year compared to December but higher in September through November. This seasonal pattern is consistent with prior expectations.

Various events related to world seafood markets (qualitative factors) also were found to be drivers of aggregate Norwegian seafood export demand. To determine what events have impacted exports across time, we sequentially tested the effects of numerous events identified in discussion with NSC officials as potentially having had an impact on aggregate Norwegian seafood export demand in various years. Of those events, four were found to be clearly statistically significant over the study period (Table 2). An 'EU trout tariff' reduced Norwegian seafood export demand by 10.6\% between January 2004 and September 2008. A 'punitive duty by the United States on imports of Norwegian salmon' diminished Norwegian seafood export demand by $15.2 \%$ in September 2007. Norwegian 'free trade agreements with South Africa and with South Korea' increased Norwegian seafood export demand by $23.6 \%$ in September 2010. Finally, 'the implementation of the maximum allowable biomass regime' in Norway to promote sustainable growth of Norwegian salmon production raised Norwegian seafood export demand by 15.6\% in June 2006.

A growing effort across the EU to promote fish consumption by raising consumer awareness of the health/ nutritional benefits of fish reportedly was a factor in a turnaround in EU per capita fish consumption after 2012 (EUMOFA, 2017). The coefficient of an indicator variable (YR_1317) to account for those effects was positive as expected but not statistically significant (Table 2).

Most importantly, the econometric analysis provides evidence that NSC expenditures had a positive and statistically significant impact on the aggregate export demand for Norwegian seafood products over the study period. In analyzing that relationship, we considered polynomial distributed lags of NSC expenditures of orders 2 and 3 with and without endpoint restrictions for lag lengths of 1 through 12 months. The specification which minimizes the model selection criteria (AIC, SIC, and HQC) was a second-degree polynomial with endpoint constraints together with a lag of five months. Thus, the impact of NSC export promotion is not felt all at once but instead grows from the current period impact through the second and third months out and subsequently dissipates over the fourth and fifth months. This finding is consistent with prior expectations based on evaluations of other export promotion programs. Specifically, the econometric results indicate a

\footnotetext{
${ }^{13}$ Econometric analyses in general principally rely on data that have unit roots. In this analysis, however, the continuous predetermined variables are stationary based on the use of Augmented Dickey-Fuller (ADF) tests.
} 
short-run (contemporaneous) elasticity of NSC export promotion of 0.0167 with a long-run (cumulative) elasticity of 0.1558 (see Table 2).

Although somewhat higher than reported by the NSC salmon promotion studies in Table 1, the estimated long-run promotion elasticity for NSC seafood promotion is substantially lower than consistently reported by studies of U.S. export promotion programs including, for example, 0.51 for apples (Rosson et al., 1986); 0.165 for grapefruit (Fuller et al., 1992); 0.477 for frozen potatoes (Lanclos et al., 1997); 0.53 for pecans (Onunkwo and Epperson, 2000); 0.625 for poultry (Shahid and Gempesaw, 2002); 0.205 for rice, 0.616 for wheat, and 0.269 for sorghum (Rusmevichientong and Kaiser, 2011); 0.273 for dairy (Song and Kaiser, 2016); and 0.177 for high value U.S. agricultural products (Williams et al., 2016) among others.

\subsection{Simulation analysis}

Three sets of alternative effects of the NSC promotion program on Norwegian seafood export volume, price, and value were simulated with the model using the econometric results from estimating the parameters of export demand Equation 8 which correspond to the three alternative Norwegian export supply elasticities considered in the analyses $(0,0.5$, and 1.0). Although the excise tax effects of the promotion are built into the simulations following Chang and Kinnucan (1991), the analysis does not consider potential spillover effects of export promotion on the domestic Norwegian fish market. However, exports represent 90-95\% of Norwegian fish production so any spillover effect is likely to be small.

The simulation analysis results indicate that, over January 2003 through December 2017, the lift ${ }^{14}$ to the average monthly volume of seafood exports from the investment by Norwegian stakeholders in seafood export promotion ranged from zero in the case of strict limits on export supplies (perfectly inelastic export supply) to no more than about 10,390 $\mathrm{mt}$ (6.1\%) (export supply elasticity of 1.0) (Table 3). More plausibly, the lift was about 7,000 $\mathrm{mt}(4.0 \%)$ assuming a relatively (but not perfectly) inelastic Norwegian seafood export supply (Table 3). Over the entire period, the maximum lift to Norwegian seafood exports was about 1.8 million mt but about 1.2 million $\mathrm{mt}$ at a more plausible export supply elasticity of 0.5 .

Over the same period, the NSC promotion lift to the average monthly price of Norwegian seafood exports ranged from a low of $1.69 \mathrm{NOK} / \mathrm{kg}(7.3 \%)$ to a high of $3.35 \mathrm{NOK} / \mathrm{kg}(16.8 \%)$ from unitary elastic to perfectly inelastic export supply curves (Table 3 ). At the mean export supply elasticity of 0.5 , the average monthly price lift was $2.24 \mathrm{~kg} / \mathrm{NOK}(9.9 \%)$. Together, the lift to the average monthly volume and price of Norwegian seafood exports from NSC export promotion resulted in a corresponding range in the average monthly lift to the value of Norwegian export revenue from a low of 521.2 million NOK (11.9\%) to a high of 578.0 million NOK (13.2\%) and 536.2 million NOK (12.2\%) at the mean elasticity of 0.5 . The corresponding export revenue lift over the entire period ranged from 89.6 billion NOK to 99.4 billion NOK. Accounting for the additional costs of exporting a larger volume of seafood, the average monthly lift to industry profit from the NSC promotion ranged from 276.9 million NOK (12.6\%) to 578.0 million NOK (26.4\%) from unitary to perfectly inelastic export supply curves (Table 3 ). At the more plausible mean export supply elasticity (0.5), the average monthly lift to the Norwegian seafood industry profit was about 374.5 million NOK (17.1\%). The corresponding industry profit lift over the entire period of analysis ranged from 47.6 billion NOK to 99.4 billion NOK.

Note that as the excess supply elasticity increases, the estimated lift to the aggregate export volume increases while the lift to the average export price declines. In consequence, the export revenue lift does not change much across the three export supply elasticity levels considered. The relative stability of the export revenue lift estimates across the three alternative elasticities is largely the result of an estimated price elasticity of Norwegian seafood export demand of just less than unity (-0.974) (see Table 2). The wider range in effects

$\overline{14}$ The addition to total sales value, price, volume, or other measures as a result of promotion. 
on industry profit occurs because the additional costs of exporting decline as export revenue increases at lower export supply elasticities.

\subsection{Benefit-cost calculations}

The simulation results indicate that the NSC promotion program had positive effects on the Norwegian seafood industry over 2003 through 2017. A critical concern to those who pay for the promotion, however, is whether the gains achieved were sufficient to more than pay for the cost of the program. That is, has the program run at a profit or a loss over time? If the cost of promotion outpaced the gains, then investment in the NSC promotion program should be discontinued. On the other hand, if the returns generated exceeded the costs, the program would be deemed a successful investment strategy for the Norwegian seafood industry.

Based on Equations 5 through 7, three sets of BCRs for the NSC seafood export promotion program (the GBCR, the NBCR, and the SBCR) were calculated for the period of January 2003 to December 2017 from the range of simulation results corresponding to the three alternative export supply elasticities considered (Table 4). A BCR that is greater than 1 is interpreted to mean that the program has more than paid for itself. Otherwise, the program would be considered to have created an economic loss because the benefit generated would be less than the cost of the program.

The estimated GBCR and NBCR of the NSC seafood export promotion program over the study period based on Equations 5 and 6 ranged from 18.9 to 20.9 and from 17.9 to 19.9, respectively, from the high (1.0) to the low (0.0) alternative export supply elasticity and were 19.4 and 18.4, respectively, at the mean elasticity of 0.5 (Table 4). That is, every NOK invested in promotion by the Norwegian seafood industry through the payment of the export levy increased Norwegian seafood export revenue by between about 18 NOK and $20 \mathrm{NOK}$ after subtracting the promotion expenditures (a cost to exporters) out of the additional revenue earned. The calculated SBCR based on Equation 6 using Equation 7 implies a range in the net addition to

Table 3. Estimated lift from the Norwegian seafood export promotion program over alternative export supply elasticities, 2003-2017.

\begin{tabular}{|c|c|c|c|}
\hline \multirow[t]{2}{*}{ Lift $^{1}$ to: } & \multicolumn{3}{|c|}{ Alternative export supply elasticities } \\
\hline & $\mathbf{0}$ & 0.5 & 1 \\
\hline \multicolumn{4}{|l|}{ Exports (metric tons) } \\
\hline All years & 0 & $1,196,696$ & $1,787,026$ \\
\hline Average monthly & 0 & 6,958 & 10,390 \\
\hline$\%$ & 0 & 4.0 & 6.1 \\
\hline \multicolumn{4}{|c|}{ Export price $\left(\mathrm{NOK}^{2} / \mathrm{kg}\right)$} \\
\hline Average monthly & 3.35 & 2.24 & 1.69 \\
\hline$\%$ & 16.8 & 9.9 & 7.3 \\
\hline \multicolumn{4}{|c|}{ Export revenue (million NOK) } \\
\hline All years & 99,419 & 92,230 & 89,646 \\
\hline Average monthly & 578.0 & 536.2 & 521.2 \\
\hline$\%$ & 13.2 & 12.2 & 11.9 \\
\hline \multicolumn{4}{|c|}{ Norwegian seafood industry profit (million NOK) } \\
\hline All years & 99,419 & 64,412 & 47,624 \\
\hline Average monthly & 578.0 & 374.5 & 276.9 \\
\hline$\%$ & 26.4 & 17.1 & 12.6 \\
\hline
\end{tabular}


Norwegian economic welfare (industry profit) of between $9.0 \mathrm{NOK}$ and 19.9 NOK per NOK spent by the NSC on seafood export promotion and was $12.6 \mathrm{NOK}$ at the mean export supply elasticity (0.5) (Table 4$)^{15}$.

These calculated BCRs compare well to the 10.8 average BCR estimated across the many U.S. agricultural commodity export promotion programs (Williams et al., 2016). The SBCR result also is similar to that calculated by Williams et al. (2016) for the USDA export market development program of 13.9. The SBCR range is above the range of 2.56-3.03 reported by Kinnucan and Myrland (2002) for salmon promotion but is more in line with the 7.95 reported by Xie (2015) and the range of 4.95-9.53 reported by Kaiser (2015) (see Table 1). The SBCR range is substantially higher than calculated for cod (4.56) and skrie (1.02) by CAPIA (2016).

\footnotetext{
$\overline{15}$ Kinnucan and Myrland (2000) elegantly show that in calculating the optimal advertising intensity (and, thus, the BCR) when advertising is funded by an ad valorem tax, as is the case for the NSC seafood export promotion program, the supply elasticity does not appear in the optimality condition. Thus, the SBCR in that case is invariant to the supply elasticity when calculating the optimal levy and, thus, the optimal level of promotion expenditures. However, this is not an optimality analysis. The SBCR is invariant to the supply elasticity only if the amount spent for promotion changes proportionally to the change in producer surplus as the supply elasticity changes as occurs with an ad valorem tax when promotion expenditures are assumed to be endogenous (as required in the optimality conditions). In contrast, this analysis considers the effects of a historically fixed level of promotion expenditures given different assumptions on the level of export supply responsiveness to price. Thus, the expenditures do not change as the supply elasticity changes because the expenditure levels are fixed (exogenous) historically in the analysis. Kinnucan and Myrland (2000) ask what level the advertising levy (and, thus, advertising expenditures) should be to maximize producer surplus. In contrast, we ask what the producer surplus and corresponding SBCR were over a historical period given the advertising expenditures that actually occurred. The total gain in producer surplus over the period of analysis is lower (the numerator in the SBCR calculations) with higher supply elasticities as should be the case, but the actual expenditures over that same period of analysis (the denominator in the BCR calculations) remain the same in each case. Thus, the SBCR is lower at successively higher supply elasticities.
}

Table 4. Estimated export revenue effects and benefit-cost ratios for the NSC seafood export promotion program, 2003-2017. ${ }^{1}$

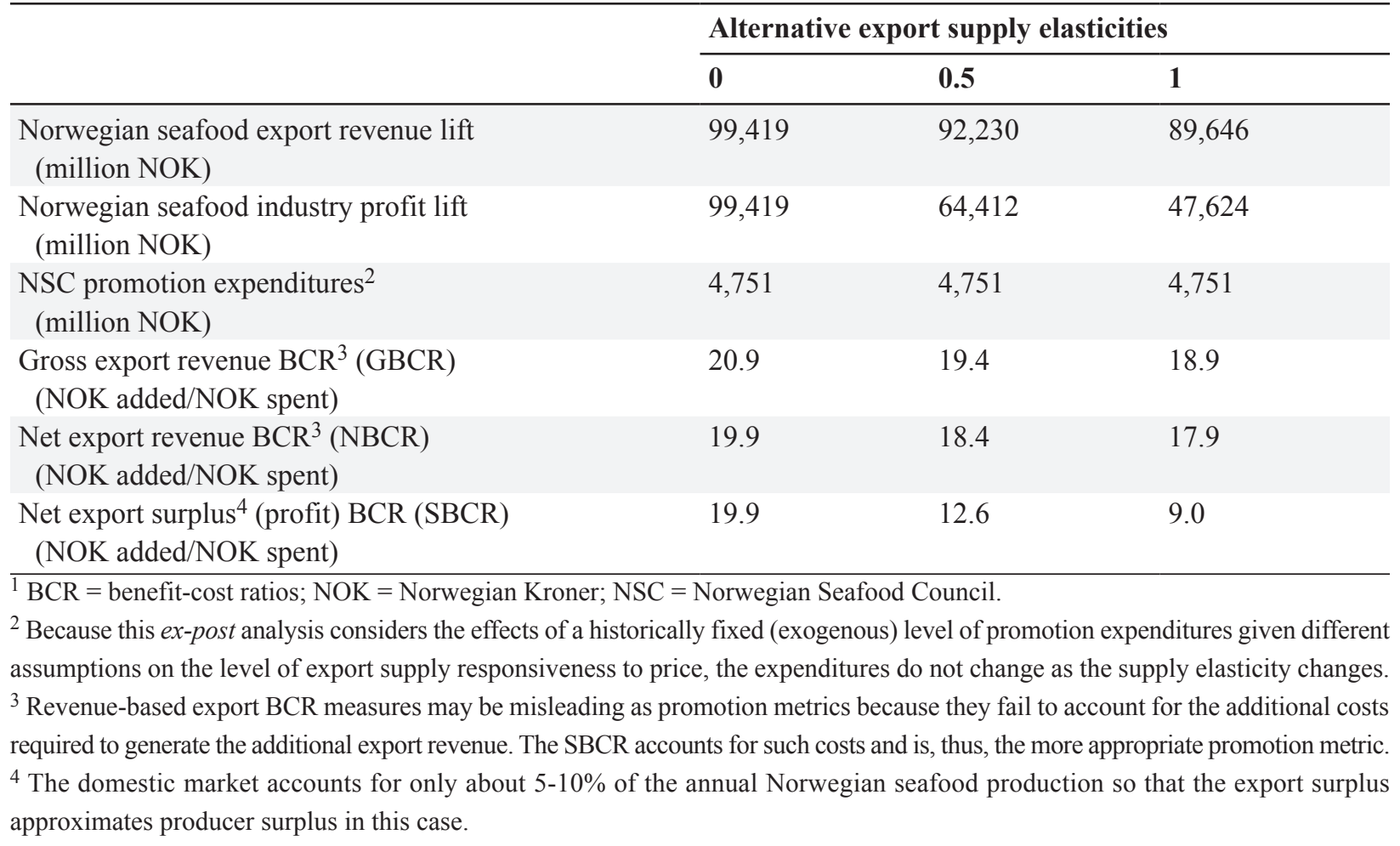




\section{Conclusions}

The general conclusion of this study is that the NSC seafood export promotion program effectively enhanced the foreign demand for Norway's seafood exports at a high return to stakeholders over 2003 to 2017. Although we consider a range of possible outcomes corresponding to a reasonable range of alternative estimates of the price elasticity of Norwegian seafood exports, the most plausible result given the government-imposed controls on Norwegian seafood production is that the NSC promotion program had only a small additive effect on the Norwegian seafood export volume over the 2003 to 2017 period of analysis. The primary effect of the promotion program was to drive the price of exported Norwegian seafood up by as much as $17 \%$ depending on the elasticity of the export supply of Norwegian seafood. Assuming a reasonably low elasticity of 0.5 for the Norwegian seafood export supply as a result of quota-imposed restrictions on Norwegian seafood production, particularly production by fisheries, the estimated addition to the Norwegian seafood export volume from NSC promotion was about 4\% on average over the 2003 to 2017 period of analysis with a $10 \%$ increase in the export price resulting in a $12 \%$ increase in export revenue. The corresponding increase in the Norwegian seafood industry profit was about $17 \%$.

The ratio between the gain in Norwegian seafood industry profit and the cost of the promotion (the average profit BCR) ranged between 9.0 and about 20, a result that is generally consistent with equivalent BCRs reported by studies of U.S. export promotion programs (Williams et al., 2016). As also concluded by most of those studies for their respective promotion programs, the robust BCRs estimated for the NSC seafood generic export promotion program suggest that the Norwegian seafood industry is heavily underinvesting in seafood export promotion. In other words, the actual promotion levies charged on Norwegian seafood exports are much below the optimal levels.

Although finding that the effect of NSC export promotion expenditures on Norwegian seafood exports was positive and statistically significant over the period of analysis (2003 to 2017), the study also found that the full effect was not felt in the month of expenditure but rather over a period of five months. The corresponding short-run elasticity of NSC export promotion was estimated to be 0.0167 and 0.1558 in the long-run.

A notable driver of Norwegian seafood exports was the real, exchange-rate-adjusted price of Norwegian seafood. Other statistically significant drivers included consumer purchasing power in importing countries (a trade-weighted, deflated, and exchange-rate-adjusted GDP of importing countries), seasonality, and several events related to the Norwegian and global seafood industries.

\section{Acknowledgements}

We gratefully acknowledge the assistance of the Norwegian Seafood Council staff, particularly Dr. Asbjørn Warvik Rørtveit, former Director of Market Insight and Amund Bråthen, former Market Insight Advisor, who openly shared NSC financial data, export data, and expertise on the Norwegian seafood industry with us. Nevertheless, the findings and conclusions of the research reported here are those of the authors and do not necessarily represent the views of the Norwegian Seafood Council or of Texas A\&M University.

This research was supported by the Norwegian Seafood Council.

\section{Disclosure statement}

There are no conflicts of interest to report. 


\section{References}

Andersen, T.B., K.H. Roll and S. Tveterås. 2008. The price responsiveness of salmon supply in the short and long run. Marine Resource Economics 23(4): 425-438.

Anderson, J.L., F. Asche and T. Garlock. 2018. Globalization and commoditization: the transformation of the seafood market. Journal of Commodity Markets 12: 2-8.

Arnason, R., L.K. Sandal, S.I. Steinshamm and N. Vestergaard. 2004. Optimal feedback controls: comparative evaluation of the cod fisheries in Denmark, Iceland, and Norway. American Journal of Agricultural Economics 86(2): 531-542.

Asche, F. 2009. Adjustment cost and supply response in a fishery: a dynamic revenue function. Land Economics 85(1): 201-215.

Asche, F., S.C. Kumbhakar and R. Tveterås. 2007. Testing cost versus profit functions. Applied Economics Letters 14(10): 715-718.

Asheim, L.J., R.E. Dahl, S.C. Kumbhakar, A. Ogelend and R. Tveterås. 2011. Are prices or biology driving the short-term supply of farmed salmon? Marine Resource Economics 26(4): 343-357.

Belsley, D.A., E. Kuh and R.E. Welsch. 1980. Regression diagnostics: identifying influential data and sources of collinearity. Wiley and Sons, New York, NY, USA.

Bergesen, O. and R. Tveterås. 2019. Innovation in seafood value chains: the case of Norway. Aquaculture Economics and Management 23(3): 292-320.

Besson, M., I.J.M. De Boer, M. Vandeputte, J.A.M. Van Arendonk, E. Quillet, H. Komen and J. Aubin. 2017. Effect of production controls on economic and environmental values of growth rate and feed efficiency in sea cage fish farming. PLOS ONE 12(3): e0173131.

Breusch, T.S. 1978. Testing for autocorrelation in dynamic linear models. Australian Economic Papers 17: 334-355.

CAPIA AS. 2016. Effect of generic marketing of 'Skrei' and 'Fresh Cod'. Unpublished report to the Norwegian Seafood Council. Norwegian Seafood Council, Trømso, Norway.

Capps Jr, O. and G.W. Williams. 2011. Is the cotton checkoff program worth the cost? Journal of Cotton Science 15(2): 109-126.

Carman, H.F. and R.D. Green. 1993. Commodity supply response to a producer-financed advertising program: the California avocado industry. Agribusiness: an International Journal 9(6): 605-621.

Chang, H.S. and H.W. Kinnucan. 1991. Economic effects of an advertising excise tax. Agribusiness: an International Journal 7(2): 165-171.

Cojocaru, A., F. Asche, R.B. Pincinato and H.-M. Straume. 2019. Where are the fish landed? An analysis of landing plants in Norway. Land Economics 95(2): 246-257.

European Market Observatory for Fisheries and Aquaculture products (EUMOFA). 2017. EU consumer habits regarding fishery and aquaculture products - final report. Directorate-General for Maritime Affairs and Fisheries of the European Commission, Brussels, Belgium. Available at: https://tinyurl. com/ybccw $82 \mathrm{z}$

Forker, O.D. and R.W. Ward. 1993. Commodity advertising: the economics and measurement of generic programs. Lexington Books, New York, NY, USA.

Fuller, S., H. Bello and O. Capps, Jr. 1992. Import demand for U.S. fresh grapefruit: effect of U.S. promotion programs and trade policies of importing nations. Southern Journal of Agricultural Economics 24: 251-260.

Ghosh, S. and G.W. Williams. 2016. Generic advertising of U.S. lamb. International Journal of Food and Agribusiness Marketing 28(4): 373-393.

Godfrey, L.G. 1978. Testing against autoregressive and moving average error models when the regressors include lagged dependent variables. Econometrica 46: 1293-1301.

Guttormsen, A.G. and K.H. Roll. 2011. Technical efficiency in a heterogeneous fishery. Marine Resource Economics 26(4): 293-308.

Hausman, J.A. 1978. Specification tests in econometrics. Econometrica 46(6): 1251-1271.

Hersoug, B. 2015. The greening of Norwegian salmon production. Maritime Studies 14: 16-34. 
International Monetary Fund (IMF). 2018. International financial statistics. Available at: https://tinyurl. $\mathrm{com} / \mathrm{ybj} 4 \mathrm{bq} 8 \mathrm{~h}$

Kaiser, H.M. 2015. Economic analysis of Norwegian Seafood Council salmon export promotion to the European Union. Unpublished report to Norwegian Seafood Council. Norwegian Seafood Council, Tromsø, Norway.

Kinnucan, H.W. and C.R. Clary. 1995. Brand versus generic advertising: a conceptual framework with an application to cheese. Agribusiness: an International Journal 11(4): 355-369.

Kinnucan, H.W. and H. Cai. 2011. A benefit-cost analysis of U.S. agricultural trade promotion. American Journal of Agricultural Economics 93(1): 194-208.

Kinnucan, H.W. and L. Gong. 2014. Goodwill and export promotion dynamics. Journal of Agricultural and Applied Economics 46(1): 73-88.

Kinnucan, H.W. and Ø. Myrland. 2000. Optimal advertising levies with application to the Norway-EU Salmon Agreement. European Review of Agricultural Economics 27(1): 39-57.

Kinnucan, H.W. and Ø. Myrland. 2001. A note on measuring returns to nonprice export promotion. Agribusiness: an International Journal 17(3): 423-433.

Kinnucan, H.W. and Ø. Myrland. 2002. Relative impact of the Norway-EU Salmon Agreement: a midterm assessment. Journal of Agricultural Economics 53(2): 195-219.

Kinnucan, H.W. and Ø. Myrland. 2003. Free-rider effects of generic advertising: the case of Salmon. Agribusiness: an International Journal 19(3): 315-324.

Kinnucan, H.W. and Ø. Myrland. 2006. The effectiveness of antidumping measures: some evidence for farmed Atlantic salmon. Journal of Agricultural Economics 57(3): 459-477.

Kinnucan, H.W., H-S. Chang and M. Venkateswaran. 1993. Generic advertising wearout. Review of Marketing and Agricultural Economics 61(3): 401-415.

Kinnucan, H.W., R.G. Nelson and H. Xiao. 1995. Cooperative advertising rent dissipation. Marine Resource Economics 10(4): 373-384.

Lanclos, D., S. Devadoss and J. Guenthner. 1997. Impacts of foreign direct investment and advertising on the export demand for U.S. frozen potatoes. Agribusiness: an International Journal 13: 273-284.

Lee, J.Y. and M.G. Brown. 1986. Economic effectiveness of brand advertising programs for U.S. orange juice in the European market: an error component analysis. Journal of Agricultural Economics 37(3): 385-394.

Love, H.A., J.J. Porras and R. Shumway. 2001. Measuring the effectiveness of non-price export promotion using a supply-side approach. Empirical Economics 26(2): 367-389.

Msangi, S., M. Kobayashi, M. Batka, S. Vannuccini, M. Dey and J. Anderson. 2013. Fish to 2030: prospects for fisheries and aquaculture. Report No. 83177-GLB. World Bank, Washington, DC, USA, 102 pp. Available at: http://www.fao.org/3/i3640e/i3640e.pdf

Myrland, Ø. and H.W. Kinnucan. 2000. Effects of generic advertising on consumers' attitudes, revealed preferences, and at-home food consumption of salmon in Germany and France. In: Johnston, R.S. (ed.) Proceedings of the International Institute of Fisheries Economics and Trade. Oregon State University, Corvallis, OR, USA. Available at: https://inyurl.com/y7qld3yp

Nerlove, M. and F.V. Waugh. 1961. Advertising without supply control: some implications of a study of the advertising of oranges. Journal of Farm Economics 43(4): 813-837.

Nerlove, M. and K.J. Arrow. 1962. Optimal advertising policy under dynamic conditions. Economica 114: 129-142.

Norwegian Seafood Council (NSC). 2018. Market insight. Available at: https:/en.seafood.no/market-insight/

Onunkwo, I.M. and J.E. Epperson. 2000. Export demand for U.S. pecans: impacts of U.S. export promotion programs. Agribusiness: an International Journal 16: 253-266.

Pascoe, S. and S. Mardle. 1999. Supply response in fisheries - the North Sea. Research paper 143. Centre for the Economics and Management of Aquatic Resources, University of Portsmouth, Portsmouth, UK. Available at: http://www.vliz.be/en/imis?module $=$ ref\&refid $=72729$

Reimer, J.J., G.W. Williams, R.M. Dudensing and H. Kaiser. 2017. Agricultural export promotion programs create positive economic impacts. Choices 32(3). 
Rocha-Aponte, F. and S. Tveterås. 2019. On the drivers of cost changes in the Norwegian salmon aquaculture sector: a decomposition of a flexible cost function from 2001 to 2014. Aquaculture Economics and Management 23(3): 276-291.

Rosson, C., M. Hammig and J. Jones. 1986. Foreign market promotion programs: an analysis of promotion response for apples, poultry, and tobacco. Agribusiness: an International Journal 2: 33-42.

Rusmevichientong, P. and H.M. Kaiser. 2011. Are there halo effects of U.S. grains export promotion? Applied Economics 43: 1435-1446.

Salvanes, K.G. and D. Squires. 1995. Transferable quotas, enforcement costs and typical firms: An empirical application to the Norwegian trawler fleet. Environmental and Resource Economics 6(1): 1-21.

Shahid, A. and C.M. Gempesaw II. 2002. The role of promotion programs for U.S. poultry exports. Agricultural and Resource Economics Review 31: 59-70.

Song, L. and H.M. Kaiser. 2016. An economic evaluation of market development programs for U.S. dairy products. Applied Economics 48(3): 212-221.

Steen, F., F. Asche and K.G. Salvanes. 1997. The supply of salmon in EU: a Norwegian aggregated supply curve. SNF Working Paper 53/97. Centre for Fisheries Economics, Norwegian School of Economics and Business, Bergen, Norway.

Stewart, D.W. and M.A. Kamins. 2002. Marketing communications. In: Weitz, B. and R. Wensley (eds.) Handbook of Marketing. Chapter 12. Sage Publications, London, UK, pp. 282-311.

Tveterås, S., F. Asche, M.F. Bellemare, M.D. Smith, A.G. Guttormsen, A. Lem, K. Lien and S. Vannuccini. 2012. Fish is food - the FAO's fish price index. PLoS ONE 7(5): e36731.

United States Department of Agriculture (USDA). 2018. Market development. Foreign Agriculture Service. Available at: https://www.fas.usda.gov/topics/market-development

Ward, R.M. 2006. Commodity checkoff programs and generic advertising. Choices 21(2): 55-60.

Ward, R.W. and B.L. Dixon. 1989. Effectiveness of fluid milk advertising since the Dairy and Tobacco Adjustment Act of 1983. American Journal of Agricultural Economics 76(3): 730-740.

Williams, G.W. and O. Capps, Jr. 2006. Overview: commodity checkoff programs. Choices 21(2): 53-54.

Williams, G.W. and O. Capps, Jr. 2018. Generic promotion of sorghum for food and industrial uses. International Journal of Food and Agribusiness Marketing 32(1): 13-29. https://doi.org/10.1080/0 8974438.2018.1533510

Williams, G.W., C.R. Shumway and H.A. Love. 2002. Returns to soybean producers from investments in promotion and research. Agricultural and Resource Economics Review 31(1): 97-111.

Williams, G.W., J.J. Reimer, R.M. Dudensing, B.A. McCarl, H.M. Kaiser and J. Somers. 2016. Economic impact of USDA export market development programs. Informa Economics, IEG, New York, NY, USA, Available at: https://tinyurl.com/yach7e22

Williams, G.W., O. Capps, Jr. and M.A. Palma. 2008. Effectiveness of marketing promotion programs: the case of Texas citrus. HortScience 43(2): 385-392.

Williams, G.W., O. Capps, Jr. and T. Dang. 2010. Does lamb promotion work? Agribusiness: an International Journal 26(4): 536-556.

$\mathrm{Wu}, \mathrm{D} . \mathrm{-M}$. 1973. Alternative tests of independence between stochastic regressors and disturbances. Econometrica 41(4): 733-750.

Xie, J. 2008. Halo effect of Norwegian salmon promotion on EU salmon demand. IIFET 2008 Vietnam Proceedings. University of Tromsø, Tromsø, Norway. Available at: https://tinyurl.com/y8uy5sss

Xie, J. 2015. Testing advertising-induced rotation of demand curves in the EU salmon market. Aquaculture Economics and Management 19(2): 175-191.

Xie, J., H.W. Kinnucan and Ø. Myrland. 2009. Demand elasticities for farmed salmon in world trade. European Review of Agricultural Economics 36(3): 425-445. 
